University of Nebraska - Lincoln

DigitalCommons@University of Nebraska - Lincoln

Faculty Publications from the Harold W. Manter Laboratory of Parasitology

$12-1969$

\title{
Parasitic Organisms in the Blood of Arvicoline Rodents in Alaska
}

\author{
Francis H. Fay \\ United States Department of Health, Education and Welfare
}

Robert L. Rausch

University of Washington, rausch@uw.edu

Follow this and additional works at: https://digitalcommons.unl.edu/parasitologyfacpubs

Part of the Parasitology Commons

Fay, Francis H. and Rausch, Robert L., "Parasitic Organisms in the Blood of Arvicoline Rodents in Alaska" (1969). Faculty Publications from the Harold W. Manter Laboratory of Parasitology. 370.

https://digitalcommons.unl.edu/parasitologyfacpubs/370

This Article is brought to you for free and open access by the Parasitology, Harold W. Manter Laboratory of at DigitalCommons@University of Nebraska - Lincoln. It has been accepted for inclusion in Faculty Publications from the Harold W. Manter Laboratory of Parasitology by an authorized administrator of DigitalCommons@University of Nebraska - Lincoln. 


\title{
PARASITIC ORGANISMS IN THE BLOOD OF ARVICOLINE RODENTS IN ALASKA
}

\author{
Francis H. Fay and Robert L. Rausch \\ Arctic Health Research Center, Public Health Service, U. S. Department of \\ Health, Education, and Welfare, College, Alaska 99701
}

\begin{abstract}
A Grahamella-like organism (Schizomycetes: Bartonellaceae) was found in erythrocytes of laboratory-reared northern voles, Microtus oeconomus Pallas, which had been inoculated intraperitoneally with a saline suspension of ground fleas, Megabothris abantis (Roths.), from wild northern voles captured at Lower Ugashik Lake, Alaska Peninsula. A live-trapped northern vole from the same locality harbored trypanosomes referable to $T$. microti (Mastigasida: Trypanosomatidae). Two morphologically similar but biologically different strains of piroplasms (Piroplasmasida: Theileriidae) of uncertain generic status were isolated from northern voles of Ugashik Lake origin and from northern red-backed voles, Clethrionomys rutilus Pallas, from the vicinity of Anchorage, Alaska. In the natural host, these piroplasms seemed to reproduce principally by schizogony in the spleen and bone marrow, but inexperimentally infected hosts from populations occurring outside the enzootic area, intraerythrocytic fission was a common method of reproduction. The vector of these piroplasms is evidently a tick, Ixodes angustus Neumann, whose geographic distribution in Alaska coincides with that of piroplasm-induced splenomegaly in arvicoline rodents. The piroplasms have been successfully transmitted from host to host in the laboratory via ticks of this species.
\end{abstract}

An organism resembling Grahamella spp. (Schizomycetes: Bartonellaceae), a trypanosome of the $T$. lewisi group (Mastigasida: Trypanosomatidae), and two piroplasms (Piroplasmasida: Theileriidae) of uncertain status have been found by us in arvicoline rodents in Alaska. We know of only one previous record of blood parasites from such rodents at high latitudes (Quay, 1955). The finding of $T$. lewisi in Norway rats, Rattus norvegicus (Berkenhout), by Schiller (1956) comprises the only other record of hematozoa in Alaskan rodents.

The present study developed from the investigation of an irruption of voles and lemmings on the Alaska Peninsula during the summer and autumn of 1963. Of unusual interest was the marked splenomegaly observed in a high proportion of the animals. Several pathogenic or potentially pathogenic organisms were isolated from these rodents in 1963 and in subsequent investigations in the same area in 1965. These included a bacterium, Pasteurella tularensis, and a spirochete, Leptospira cf. ballum (Rausch et al., 1969; Woods, unpublished), in addition to the four blood parasites mentioned above. The piroplasms were eventually found to be the causative agents of the splenomegaly. The tick Ixodes angustus Neumann probably is the vector of these organisms under natural conditions.

Received for publication 21 February 1969.
The purpose of this paper is to report some findings concerning identification, occurrence, and geographic distribution of the parasites. The developmental cycle and pathogenicity of the piroplasms will be considered in greater detail elsewhere.

\section{MATERIALS AND METHODS}

Thin smears were prepared with blood drawn from the tail or toes of living voles and lemmings and from the axillary vein of the same individuals at necropsy. Spleen impression smears were prepared from these, as well as from snap-trapped animals. The preparations were air dried, fixed in absolute methanol, and stained by the WrightGiemsa method. The animals were examined also for ectoparasites. All experimental animals utilized in this investigation were laboratory-born and -reared; most were of known ancestry. Inoculations were intraperitoneal, with sterile, citrated, phosphate-buffered saline or modified Alsever's solution utilized as a diluent for the blood and organ suspensions.

\section{RESULTS}

\section{Grahamella-like organism}

Minute, deeply staining rods, resembling organisms identified as Grahamella spp. by several investigators (e.g., Lavier, 1921; Carini and Fonseca, 1941; Tyzzer, 1942; Baker et al., 1963), were found within erythrocytes in thin smears of blood from northern voles, Microtus oeconomus Pallas, which had been inoculated with a suspension of ground fleas. The fleas, Megabothris abantis (Roths.), were obtained 
from northern voles trapped at Lower Ugashik Lake $\left(57^{\circ} 35^{\prime} \mathrm{N}, 157^{\circ} \mathrm{W}\right)$, Alaska Peninsula, in October 1965. After storage alive in a glass vial for 2 days, the fleas were ground in $1 \mathrm{ml}$ of saline, and $0.1 \mathrm{ml}$ of this suspension was injected into each of three laboratory-reared voles. Four siblings of the experimental animals were inoculated with a suspension of ticks, Ixodes angustus Neumann, from the trapped voles, and eight white mice, Mus musculus L. (strain HA/ICR), received the remainder of the flea suspension. Smears of peripheral blood were prepared from the voles at irregular intervals from the 6th to the 99th day after inoculation; smears were prepared from the mice only on the 23rd day.

On the 6th day following inoculation, two to five Grahamella-like bodies, about 1 to 1.25 $\mu$ long by $0.25 \mu$ wide, were found in the cytoplasm of each of a few erythrocytes from the voles which had received the flea inoculum. By the 17th day, about $6 \%$ of their erythrocytes were infected with from 6 to 14 organisms per cell (Fig. 1). The number of organisms and percentage of cells infected had diminished by the 23rd day, and none was found thereafter. None of the smears from voles receiving the tick inoculum nor those from mice receiving the flea inoculum showed intraerythrocytic bodies of this kind. Neither were any Grahamella-like organisms found in smears (19th day) from two northern voles inoculated earlier (October 1963) with a suspension of 21 fleas ( $M$. abantis) from voles taken in the same area.

Tentative identification of the organisms as Grahamella sp. was based on their form, staining properties, occurrence within (rather than on) the erythrocytes, and on the brief duration of their invasive stage in the erythrocytes. Further study, by use of splenectomized animals or by culture of the organisms in vitro (Tyzzer, 1942), was not feasible.

\section{Trypanosomes}

In the blood of one of six northern voles, captured alive at Lower Ugashik Lake on 10 October 1965, were found trypanosomes referable to the T. lewisi group (Fig. 2). These occurred in smears of peripheral blood at the rate of $2 / 1,000 \mathrm{rbc}$ (about $20,000 / \mathrm{ml}$ ) for the first 18 days after capture of the host, then declined gradually to about $0.2 / 1,000 \mathrm{rbc}$ by the 48th day. None was found in smears prepared on the 54th day or at any time during the succeeding 18 months. Attempts to propagate the organism by inoculation of blood from the infected animal to laboratory-reared voles on the 54th day were unsuccessful.

Twenty-five trypanosomes from a smear prepared on 12 October were measured from camera lucida tracings, after the method utilized by Davis (1952). The dimensions of these were as follows: length overall 22.9 to $27.1 \mu$ (mean \pm standard error $=24.84 \pm$ $0.23 \mu$ ); distance from posterior tip to kinetoplast 3 to $3.5 \mu$; kinetoplast to center of nucleus 6 to $8 \mu$; center of nucleus to anterior end of body 8 to $10 \mu$; length of free flagellum 7 to $9 \mu$; width of body 1.5 to $2 \mu$; length of nucleus 1.5 to $3 \mu$; width of nucleus 0.5 to $1 \mu$. These were comparatively small organisms, with a smaller nucleus and longer flagellum than most of the recorded members of the T. lewisi group (cf. Lavier, 1921; Davis, 1952; Baker et al., 1963). Although they did not closely conform to trypanosomes designated as T. microti Laveran et Petit, 1909, for example, by Krampitz (1961), they are referable to that species on the basis of host occurrence. T. microti is believed to be hostspecific in voles of the genus Microtus (Levine, 1965).

\section{Piroplasms}

Intraerythrocytic forms of a piroplasm were first detected by us in smears of blood and spleen from northern voles captured at Lower Ugashik Lake in October 1965. Subsequently, comparable organisms were found in northern voles from Amak Island, near the western end of the Alaska Peninsula, and in meadow voles, Microtus pennsylvanicus Ord, and northern red-backed voles, Clethrionomys rutilus Pallas, from the vicinity of Anchorage. By means of intraperitoneal inoculations with citrated blood and suspensions of splenic tissue, from naturally infected northern voles and northern redbacked voles, we successfully passed the organisms to laboratory-reared arvicoline rodents of the same and several other species (Table I.) The organism from northern voles taken near Ugashik Lake was isolated in laboratoryreared voles of the same subspecies, M. $o$. 


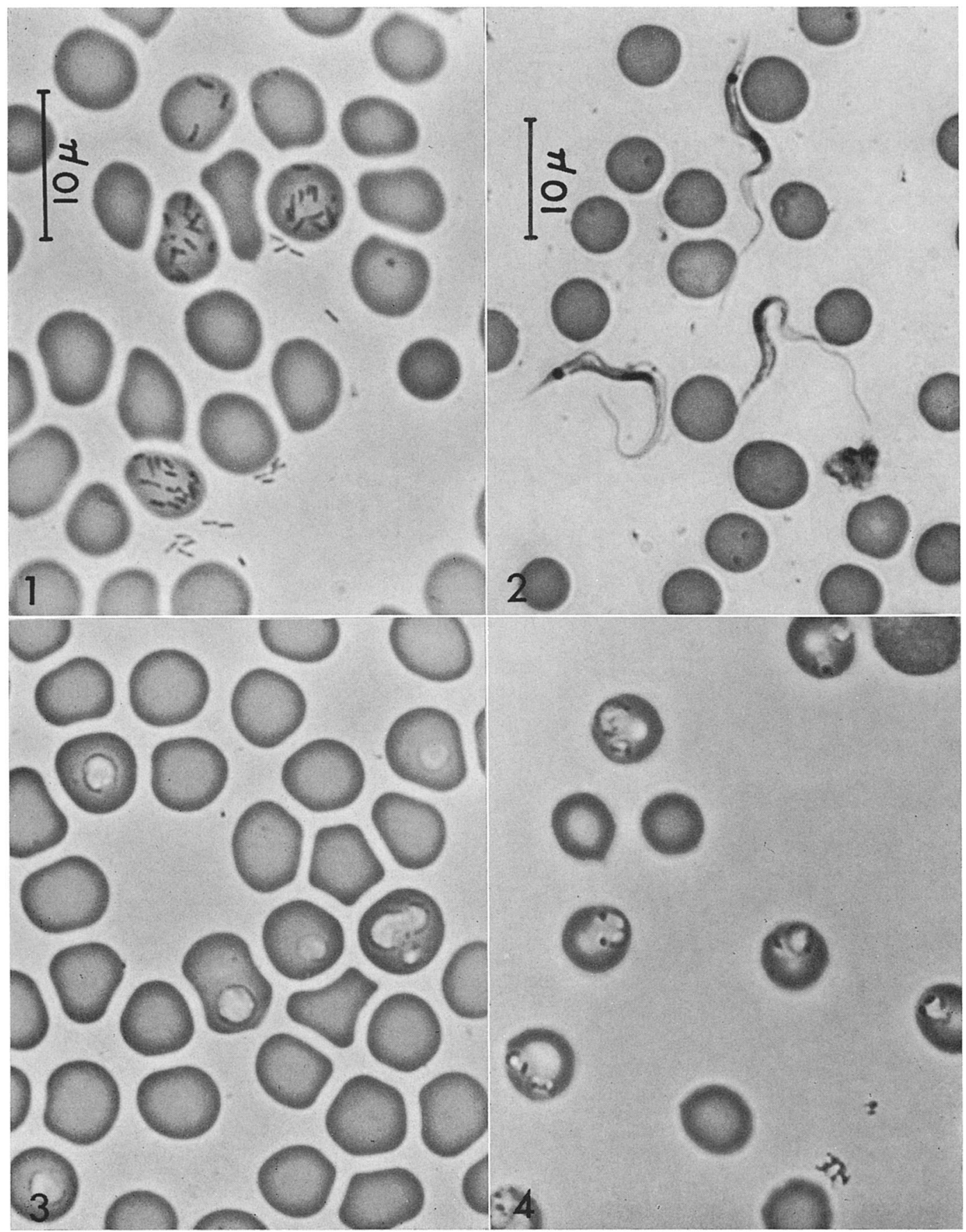

operarius (Nelson), the original stock of which was obtained near Homer, Kenai Peninsula. It has been maintained for more than 3 years by serial passage in the laboratory colony of these voles. The isolate from the red-backed voles has been maintained in a laboratory colony of C. r. dawsoni (Merriam), the original stock of which was captured in the Anchorage area. These two piroplasms, designated by us as "strains" MO-U and CR-A, 
TABLE I. Results of experimental inoculations of laboratory-reared rodents ${ }^{1}$ with citrated blood of voles harboring piroplasms. ${ }^{2}$

\begin{tabular}{|c|c|c|c|}
\hline \multirow[b]{2}{*}{ Recipients } & \multirow{2}{*}{$\begin{array}{c}\text { Origin of } \\
\text { breeding stock }\end{array}$} & \multicolumn{2}{|c|}{$\begin{array}{l}\text { Number of animals infected } \\
\text { per number inoculated } \\
\text { with each piroplasm strain }\end{array}$} \\
\hline & & Strain MO-U & Strain CR-A \\
\hline Microtus oeconomus operarius & Ugashik Lake & $15 / 17$ & $4 / 4$ \\
\hline Microtus oeconomus operarius & Homer & $25 / 25$ & $20 / 22$ \\
\hline Microtus oeconomus innuitus & St. Lawrence I. & $11 / 11$ & $0 / 1$ \\
\hline Microtus gregalis muriei & Umiat & $3 / 3$ & - \\
\hline Microtus abbreviatus fischeri & St. Matthew I. & - & $3 / 3$ \\
\hline Clethrionomys rutilus dawsoni & Anchorage & $0 / 11$ & $40 / 42$ \\
\hline Lemmus sibiricus alascensis & Pt. Barrow & $15 / 18$ & $2 / 4$ \\
\hline Dicrostonyx groenlandicus rubricatus & Pt. Barrow x Anaktuvuk Pass & $5 / 6$ & - \\
\hline Dicrostonyx groenlandicus stevensoni & Umnak Island & $6 / 7$ & $4 / 4$ \\
\hline Peromyscus maniculatus osgoodi & Jamestown, North Dakota & $0 / 4$ & $0 / 4$ \\
\hline Mus musculus (HA/ICR) & Laboratory ${ }^{3}$ & $0 / 3$ & - \\
\hline Sigmodon hispidus ssp. & Laboratory 4 & $0 / 1$ & - \\
\hline
\end{tabular}

${ }^{1}$ Also inoculated with the MO-U strain were two C. rutilus dawsoni and one Ondatra zibethicus (L.) livetrapped in the Fairbanks area. The two voles became infected but the muskrat did not.

2 Donors: Strain MO-U, Microtus oeconomus operarius (Ugashik and Homer origins), Strain CR-A, Clethrionomys rutilus dawsoni (Anchorage origin).

3 Original stock from Roswell Park Memorial Institute, Buffalo, New York.

4 From Communicable Disease Center, Atlanta, Georgia; origin of stock unknown.

respectively, are morphologically similar but biologically different, as indicated by our negative results from repeated efforts to pass strain MO-U to red-backed voles of Anchorage origin, in which strain CR-A develops readily.

The early-stage parasitemia in laboratoryreared northern voles of Ugashik Lake and Homer lineages, inoculated with strain MO-U, was characterized by an exponential increase in rate of infection of erythrocytes up to the 9 th or 10th day postinoculation. This was followed by a rapid decline to a very low level, which was sustained throughout the chronic phase of the infection. Maximal rates of infection of the erythrocytes ranged from 25 to $60 \%$ in the acute phase, which was further characterized by pseudomacrocytic anemia, oligocythemia, icterus, and splenomegaly. The anemia, oligocythemia, and icterus decreased gradually in intensity following the acute phase, whereas the splenomegaly persisted unchanged in the chronic phase.

Throughout the course of the infection, most of the affected erythrocytes in the peripheral blood harbored only a single piroplasm, usually of the circular or ring form (Fig. 3). The largest of these was about $3 \mu$ in diameter. Oval, piriform, and rod-shaped organisms were uncommon to rare; anaplasmalike forms occurred in 0.1 to $5 \%$ of the infected cells. We found no clear signs of intraerythrocytic fission at any stage of the infection, but did find a few organisms whose form was suggestive of this kind of reproduction. For example,

Figures 1-4. Parasites in the blood of northern voles, Microtus oeconomus. 1. Intra- and extraerythrocytic Grahamella-like bodies in a laboratory-reared M. o. operarius (Homer origin), 17 days after inoculation with a suspension of ground fleas from wild voles of the same subspecies (Ugashik Lakes origin). 2. Trypanosomes in a naturally infected M. o. operarius, 14 days after capture in the Ugashik Lakes district. This animal also harbored naturally acquired piroplasms (strain MO-U) and showed pseudomacrocytic anemia. 3. Piroplasms of the MO-U strain, 8 days postinoculation in a laboratoryreared $M$. o. operarius (Homer origin), showing the intraerythrocytic ring form that predominates in all stages of the parasitemia in voles of that subspecies. A discontinuous band of nuclear chromatin is evident at the periphery of the otherwise vesicular parasites. Erythrocyte at right center contains two piroplasms of unequal size, the larger of which may be in the process of division. (Scale as in Figure 1.) 4. Intraerythrocytic fission and multiple forms of piroplasms of the MO-U strain in an "atypical" host, a laboratory-reared St. Lawrence Island vole, M. o. innuitus, 10 days postinoculation. (Scale as in Figure 1.) 


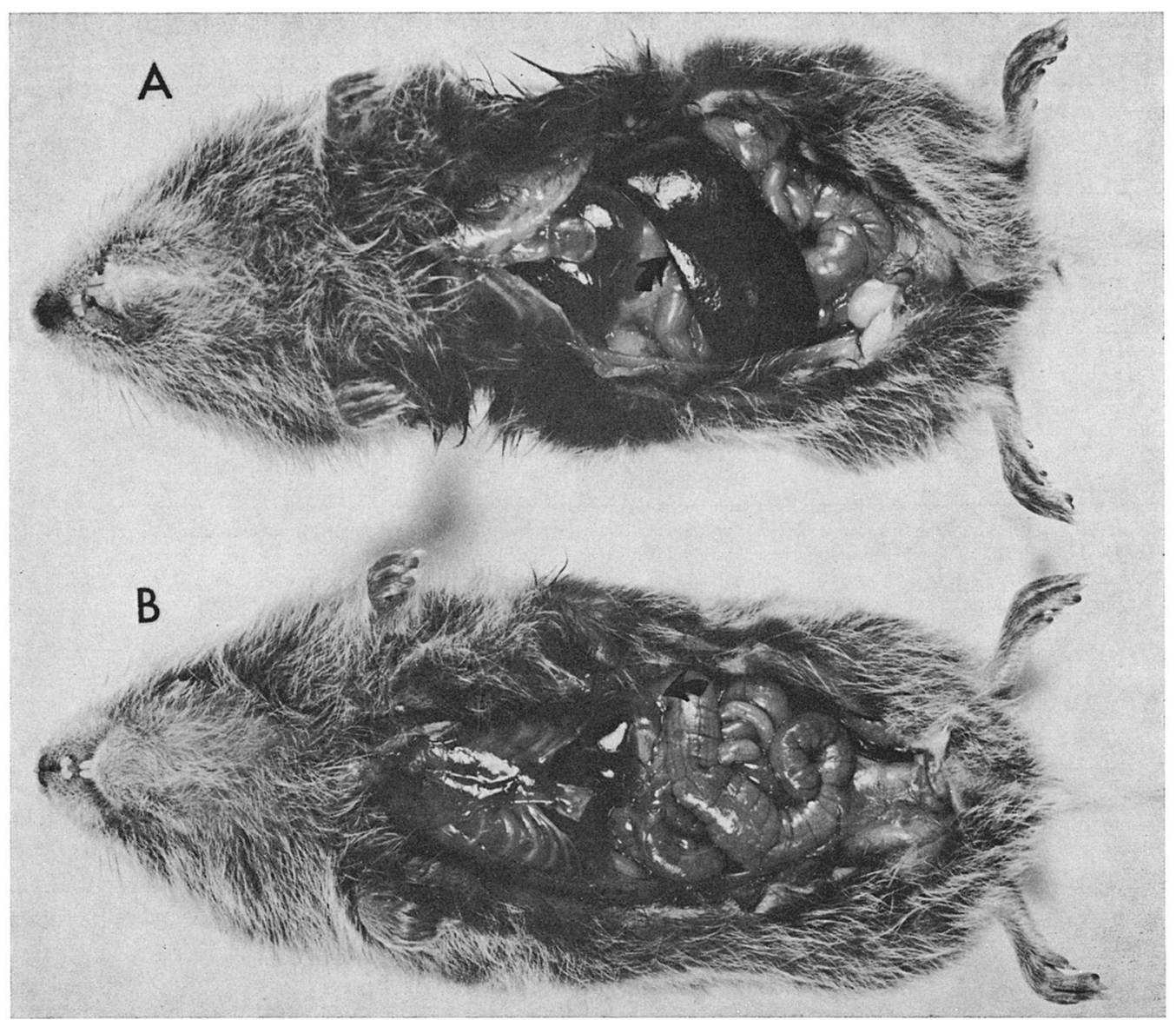

Figure 5. Piroplasm-induced splenomegaly in a northern vole, Microtus oeconomus, 14 days postinoculation. The enlarged spleen (arrow) of the infected animal (A) extends diagonally across the abdomen, while that of its normal sibling (B) lies hidden from view in its usual position laterodorsal to the stomach (arrow). The spleen of the infected animal had a volume approximately 46 times greater than that of the normal individual.

in 1,362 infected erythrocytes from four northern voles in the exponential stage (6th to 9 th day) of the developing parasitemia, 1,338 cells $(98.3 \%)$ contained only single parasites, 11 of which seemed to be partly constricted, as if undergoing division. In only three of these were the two parts approximately equal in size; in the rest they were very unequal. Twenty-two infected cells contained two ring forms, mostly unequal in size; one contained a ring and an anaplasmalike form, and one contained what appeared to be a tetrad, though not of the classic "maltese cross" form. From these findings we judge that intraerythrocytic fission is, at most, uncommon to rare and is not the principal means of repro- duction in the normal vertebrate host. The principal reproductive process may be schizogony; extracellular forms of the parasite were abundant in the spleen and bone marrow and some clumps of these resembled schizonts.

Intraerythrocytic fission was, however, a very common method of reproduction in the "atypical hosts," the voles and lemmings from arctic and insular localities in which these piroplasms apparently do not occur (see below). Diads, tetrads, and extracellular forms were abundant in the peripheral blood of these animals (Fig. 4), and a much greater proportion of the erythrocytes was invaded by the parasites, approaching $100 \%$ in the acute stage of the disease. The anemia and icterus 
TABLE II. Species of arvicoline rodents in which splenomegaly has been recorded and localities where splenomegalous individuals were captured.

\begin{tabular}{ll}
\hline \multicolumn{1}{c}{ Species } & \multicolumn{1}{c}{ Localities $^{1}$} \\
\hline Clethrionomys rutilus & Cold Bay, Ugashik Lakes, \\
& Kukak Bay, ${ }^{2}$ Anchorage, \\
& Talkeetna, Nabesna, Valdez, \\
& Yakataga \\
Microtus pennsylvanicus & Anchorage \\
Microtus oeconomus & Cold Bay, Amak Island, Uga- \\
& shik Lakes, Becharof Lake, \\
& Kukak Bay, Kodiak, Homer, \\
& Kenai, Sterling, Hope, Portage, \\
& Anchorage, Palmer, Talkeetna, \\
& Chilkat Pass (Yukon Territory, \\
& Canada) \\
Microtus gregalis & Palmer Creek (near Hope) \\
Lemmus sibiricus & Ugashik Lakes, Becharof Lake \\
Synaptomys borealis & Kenai, Portage \\
Dicrostronyx groenlandicus & Umnak Island \\
\hline
\end{tabular}

1 All localities are "Alaska" except as indicated.

2 Specimens collected by E. L. Schiller (Schiller and Rausch, 1956).

also were more extreme than in the normal hosts and were accompanied by severe hematuria and general debilitation. Whereas none of the voles of Ugashik and Homer origins died as a result of the infection, the voles and lemmings from outside the enzootic area usually died before the 15th day postinoculation.

Splenomegaly is pathognomonic for the infection in the natural hosts, since it persists in the chronic stage of the disease for the duration of life of the animal. The increased volume of the spleen, usually about 40 times that in the noninfected animal, is readily apparent and easily recognized in wild-trapped rodents (Fig. 5). We have recorded it in seven species of arvicoline rodents from 20 localities in southern Alaska and adjacent Canada (Table II). The absence of splenomegaly in several thousand rodents of the same species from western, central, and northern Alaska is taken as evidence of the absence of piroplasms in those areas.

Hematozoa of the order Piroplasmida Wenyon, 1926, are dependent on ixodid ticks as vectors, insofar as is known. Since Ixodes angustus is the only species of tick we have found on arvicoline rodents in Alaska, we consider it the most probable vector of the organisms described here. Circumstantial evidence

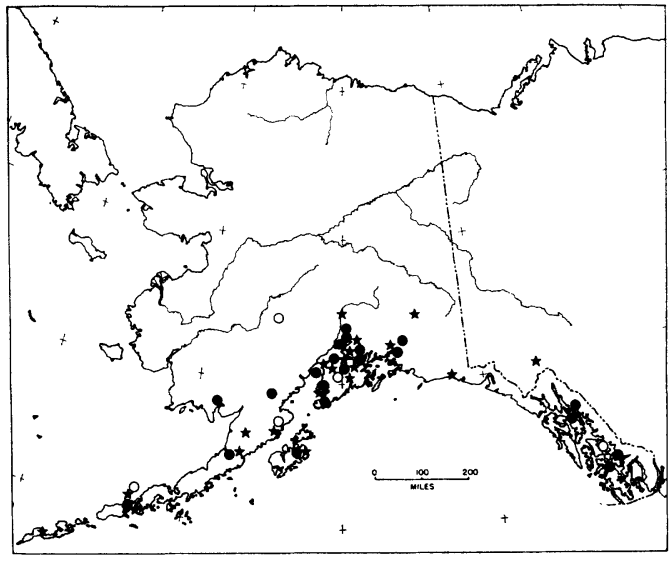

Figure 6. Geographical distribution of records of splenomegalous rodents and of ticks, Ixodes angustus, in Alaska and adjacent Canada. The rodents are indicated by stars. Published records of I. angustus (open circles) are those of Cooley and Kohls (1945) and Schiller and Rausch (1956); new records (solid dots) are summarized in Table III. Multiple records from one locality are represented by single symbols.

in support of this is found in the coincidence of the known distribution of $I$. angustus with that of splenomegalous rodents (Table III, Fig. 6 ). In addition, we have successfully transmitted organisms of strain MO-U from vole to vole via ticks of this species, reared in the laboratory. Larval ticks, engorged on an experimentally infected vole, transmitted the organism to other laboratory-reared voles on which they fed as nymphs. However, transovarial transmission from a naturally infected adult tick to its larvae did not occur, as evidenced by failure of such larvae to infect susceptible voles. Although I. angustus occurs widely on mammals in northern North America and northeastern Eurasia (Cooley and Kohls, 1945; Pomerantsev, 1950; Gregson, 1956), ticks of this species have not been implicated previously in the transmission of any pathogen. Further investigation of the role of $I$. angustus in the transmission of these piroplasms is under way in our laboratory.

The piroplasms reported previously from small rodents, e.g., by França (1912), Coles (1914), Yakimoff and Saphronowitsch (1917), and Shortt and Blackie (1965), were assigned to several genera: Smithia França, 1909, Nuttallia França, 1909, Theileria Bettencourt, 
TABLE III. New distribution records of Ixodes angustus in Alaska.

\begin{tabular}{|c|c|c|c|}
\hline Locality & Date & Host & $\begin{array}{l}\text { Collector or } \\
\text { authority }{ }^{1}\end{array}$ \\
\hline Amak Island & 4-5 Jun. 1968 & Microtus oeconomus & FHF \\
\hline Cold Bay & 8 Jun. 1968 & Clethrionomys rutilus & FHF \\
\hline Ugashik Lakes & 6-7 Oct. 1963 & $\begin{array}{l}\text { Lemmus sibiricus, } \\
\text { M. oeconomus }\end{array}$ & RLR \\
\hline Dillingham & 30 Jun. 1958 & C. rutilus & FHF \\
\hline Iliamna Lake & 28 May 1958 & C. rutilus & FSLW \\
\hline Kodiak Island & 13 Jun. 1951 & M. oeconomus & RLR \\
\hline Kalgin Island & 20 May 1952 & Tamiasciurus hudsonicus & RLR \\
\hline Anchor River & 9 Jun. 1954 & M. oeconomus & RLR \\
\hline Seldovia & 19 Jun. 1954 & T. hudsonicus & DKH \\
\hline Daniel's Lake & 15 Jul. 1952 & C. rutilus & RLR \\
\hline Hope & 23 Aug. 1952 & T. hudsonicus & RLR \\
\hline Goose Bay & 9 Jun. 1948 & Sorex sp. & JDG \\
\hline Cottonwood Creek & 10 Jun. 1948 & C. rutilus & JDG \\
\hline Hatcher Pass & 24 Jul. 1952 & Microtus sp. & RLR \\
\hline Archangel Creek & 30 May 1954 & Ochotona collaris & RLR \\
\hline Palmer & May 1951 & C. rutilus & RLR \\
\hline Peters Creek & 16, 18 Aug. 1951 & Microtus sp., C. rutilus & RLR \\
\hline Fort Richardson & 18 Aug. 1948 & Sorex sp. & JDG \\
\hline Anchorage & 19 May 1955, 13 Jul. 1956 & C. rutilus & RLR \\
\hline Anchorage & 19 Jul. 1960 & M. oeconomus & MV \\
\hline Potter & 28 Jun. 1957 & C. rutilus & RLR \\
\hline Portage & 2 Jul. 1961 & Sorex obscurus & RLR \\
\hline Valdez & 8-12 Jul. 1948 & Sorex sp., C. rutilus & JDG \\
\hline Valdez & 20 Jul. 1959 & Microtus sp. & ELK \\
\hline Thompson Pass & 13 Jul. 1948 & O. collaris & JDG \\
\hline Thompson Pass & 8 Jul. 1961 & M. oeconomus & RLR \\
\hline Juneau & $\begin{array}{l}4 \text { Oct. } 1945,29 \text { Aug. } 1948, \\
\text { 1-2 Apr. 1950, } 17 \text { Sep. } 1949\end{array}$ & T. hudsonicus & GMK \\
\hline Juneau & 22 May 1961 & Domestic dog & GMK \\
\hline Douglas Island & 5 Sep. 1949 & T. hudsonicus & GMK \\
\hline Prince of Wales I. & 23 May 1962 & Peromyscus maniculatus & GMK \\
\hline Wrangell Island & $\begin{array}{r}1,8,24 \text { Apr. 1946, } \\
6 \text { Jun. } 1946\end{array}$ & T. hudsonicus & GMK \\
\hline Wrangell & 26 Mar. 1946 & T. hudsonicus & GMK \\
\hline Wrangell & 24 Apr. 1946 & Man (on clothing) & GMK \\
\hline
\end{tabular}

${ }^{1}$ F. H. Fay, J. D. Gregson, D. K. Hilliard, E. L. Karlstrom, G. M. Kohls, R. L. Rausch, M. Voge, F. S. L. Williamson.

França, and Borges, 1907, and Babesia Starcovici, 1893, principally on the basis of the form of the intraerythrocytic stages and host occurrence, neither of which is adequate for generic determination (Neitz, 1965). For the present, we have chosen not to assign the organisms that we have found to any genus, since the taxonomy of the Piroplasmida is currently uncertain, and the diagnostic value of previously accepted morphological and biological characters of "genera" and "species" is now in doubt (Neitz, 1965). Further uncertainty about the validity of those characters is raised by the contrasting performances of the MO-U strain in normal versus atypical hosts.

The majority of genera and species of piroplasms has been described from domestic ani- mals, rather than from wild mammalian hosts. Conceivably, their structure and development in the former are atypical and more variable than in the natural hosts. The piroplasms of wild animals are little known, and their biology and enzootiology poorly understood. The finding of two kinds of these organisms, which can readily be studied in the field as well as reared in their normal hosts and hosts of several other species in the laboratory, should facilitate the acquisition of basic information for solution of some of these problems.

\section{ACKNOWLEDGMENTS}

Our field work was greatly aided by facilities provided at Lower Ugashik Lake by the late Alf Madsen of Kodiak, at Cold Bay and Amak Island by Robert D. Jones and Palmer 
Sekora of the Aleutian Islands and Izembek Bay National Wildlife Refuges, Bureau of Sport Fisheries and Wildlife, U. S. Fish and Wildlife Service, Cold Bay, and at King Salmon by Ken Middleton of the Division of Commercial Fisheries, Alaska Department of Fish and Game, King Salmon, Alaska. James E. Hemming and K. Richard Zinsmann of the Arctic Health Research Center assisted with the collection of specimens in the field; Floyd M. Seesee and Larry M. Shults, of the Center, provided records of splenomegalous rodents and assisted with inoculations and collection of data from the experimental animals; Dr. Richard B. Lyons, Mrs. Virginia R. Rausch, and Gerald C. Kelley, also of the Center, assisted with the preparation of photographs and illustrations. Ronald O. Skoog and Kenneth A. Neiland of the Division of Game, Alaska Department of Fish and Game, Anchorage, provided specimens collected by them at Becharof Lake. Dr. Glen M. Kohls, Rocky Mountain Laboratory, Public Health Service, U. S. Department of Health, Education, and Welfare, Hamilton, Montana, and Dr. John D. Gregson, Entomology Laboratory, Canada Department of Agriculture, Kamloops, British Columbia, identified ticks and provided some unpublished records of ticks collected in Alaska. Dr. George P. Holland, Canada Department of Agriculture, Ottawa, identified the fleas. To each of these individuals and their respective agencies, we express our sincere appreciation.

\section{LITERATURE CITED}

Baker, J. R., D. Chitty, And E. Phipps. 1963. Blood parasites of wild voles, Microtus agrestis, in England. Parasitology 53: 297-301.

Carini, A., and F. Fonseca. 1941. Grahamellas de dois murideos do Brasil. Arquívos de Biología 25 : $2-4$.

Coles, A. C. 1914. Blood parasites found in mammals, birds and fishes in England. Parasitology 7: 17-61.

Cooley, R. A., and G. M. Kohls. 1945. The genus Ixodes in North America. NIH Bull. No. 184, U. S. Govt. Printing Office, Washington.
Davis, B. S. 1952. Studies on the trypanosomes of some California mammals. Univ. Calif. Publ. Zool. 57: 145-250.

França, C. 1912. Sur la classification des Piroplasmes et description de deux formes de ces parasites. Arch. Inst. Bacteriol. Camara Pestnana 3 : 11-18.

Gregson, J. D. 1956. The Ixodoidea of Canada. Publ. 930, Science Service, Entomol. Div., Canada Dept. Agric., Ottawa.

Krampitz, H. E. 1961. Kritisches zur Taxonomie und Systematik parasitischer SäugetierTrypanosomen mit besonderer Beachtung einiger der in Wühlmäusen verbreiteten spezifischen Formen. Ztschr. Tropenmed. Parasit. 12: 117-137.

LAvier, G. 1921. Hémogrégarines, Grahamella, Spirochète et Trypanosome du campagnol indigène Microtus arvalis Pallas. Bull. Soc. Path. Exot. 14: 569-576.

Levine, N. D. 1965. Trypanosomes and Haemobartonella in wild rodents in Illinois. J. Prot. 12: 225-228.

Nertz, W. O. 1965. Shortcomings in the biological studies as hazards to the classification of piroplasms. Bull. Off. int. Epiz. 64: 1-16.

Pomerantsev, B. I. 1950. Ixodid ticks (Ixodidae). Fauna of the USSR, Arachnids, vol. 4, no. 2, Acad. Sci. USSR, Moscow.

QuAY, W. B. 1955. Trypanosomiasis in the collared lemming, Dicrostonyx torquatus (Rodentia). J. Parasit. 41: 562-565.

Rausch, R. L., B. E. Huntley, and J. G. BridGENS. 1969. Notes on Pasteurella tularensis isolated from a vole, Microtus oeconomus Pallas, in Alaska. Can. J. Microb. 15: 47-55.

Schiller, E. L. 1956. Ecology and health of Rattus at Nome, Alaska. J. Mammal. 37: 181188.

- AND R. Rausch. 1956. Mammals of the Katmai National Monument, Alaska. Arctic 9: 191-201.

Shortt, H. E., and E. J. Blackie. 1965. An account of the genus Babesia as found in certain small mammals in Britain. J. Trop. Med. Hyg. 68: $37-42$.

Trzzer, E. E. 1942. A comparative study of Grahamellae, Haemobartonellae and Eperythrozoa in small mammals. Proc. Am. Philosoph. Soc. 85: 359-398.

Yakimoff, W. L., and R. A. Saphronowitsch. 1917. Parasites du sang des animaux en Transcaucasie. Bull. Soc. Path. Exot. 10: 98100. 